\title{
Molecular Cloning, Transcriptome Profiling, and Characterization of Histone Genes in the Dinoflagellate Alexandrium pacificum
}

\author{
Sadaf Riaz ${ }^{1,2}$ and Zhenghong Sui ${ }^{1 *}$ \\ ${ }^{1}$ Key Laboratory of Marine Genetics and Breeding (Ocean University of China), Ministry of Education, Qingdao, 266003, P.R. China \\ ${ }^{2}$ Department of Microbiology, University of Veterinary and Animal Sciences, Lahore, Pakistan
}

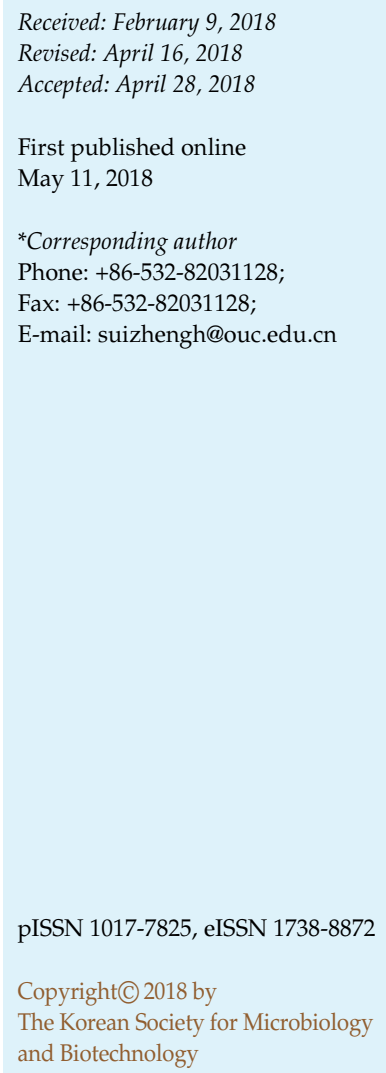

The nucleosomal organization of chromatin using histone proteins is a fundamental and ubiquitous feature of eukaryotic nuclei, with the major exception of dinoflagellates. Although a number of recent genomic and transcriptomic analyses have detected numerous histone genes in dinoflagellates, little is known about their expression. Here in, we aimed to investigate the expression pattern of histone genes under nutritional stress, and an attempt was made to detect histone expression at the protein level in Alexandrium pacificum. The presence of histones at the mRNA level was confirmed in this study by the amplification, cloning, and sequencing of 10 different genes. Relative expression profiling of these genes under different growth conditions was determined with real-time PCR and revealed considerable levels of histone transcription in nutritionally stressed cells. We were unable to detect the expression of histones at the protein level even after immunodetection and analysis using mass spectrometry, although a histone-like protein was detected as a major nuclear component. A. pacificum expresses multiple variants of histone, and protein sequences revealed both conservation and divergence with respect to other eukaryotes. We concluded that A. pacificum maintained an active transcription of histone genes within the cell, and enhanced expression of histone genes in nutritional stress strongly suggest that histones have functional significance in dinoflagellates, although expression at the protein level was below our current detection limits, which suggests a limited role of histones in DNA packaging. Finally, the plausible regulation of histone expression at the gene and protein levels in A. pacificum is discussed.

Keywords: Dinoflagellate, transcriptome, histone expression, immunodetection, mass spectrometry, histone-like protein

\section{Introduction}

Histone proteins package DNA in all eukaryotic organisms and play a key role in the regulation of gene expression [1]. Almost 147 DNA base pairs (bp) wrap an octamer of core histones (i.e., two of each of the histones H2A, H2B, H3, and $\mathrm{H} 4$ ) to make a nucleosome [2]. In addition, about $50 \mathrm{bp}$ of DNA bounded by linker histones are present between nucleosomes; these histone proteins bind to replicated DNA and are among the most stable cell proteins [3].

The exception to this nearly universal organization is dinoflagellates. Members of this group of unicellular protists play significant roles in marine food webs and ecology [4]; the dinoflagellate Alexandrium pacificum [5] (previously named as Alexandrium catenella) [6], for example, is the primary cause of paralytic shellfish poisoning in bivalves [7]. Dinoflagellates are unusual in the possession of a number of uncommon features, including a differently organized genome in their mitochondria [8] and plastids [9]. In particular, the nuclei of dinoflagellates are very unusual; at one point, these protists were thought to be intermediate between prokaryotes and eukaryotes (mesokaryotes) [10]. The DNA of dinoflagellates is not characterized by nucleosomal packaging [11] and no pattern 
of bands is seen on gels following micrococcal nuclease digestion [12]. Dinoflagellates also have very low levels of basic proteins (approx. 10\% compared with DNA), whereas other eukaryotic nuclei contain up to 50\% [13]. Finally, the chromosomes of dinoflagellates remain permanently condensed during the cell cycle [14].

It has been proposed that, instead of true histones, dinoflagellates possess histone-like proteins (HLPs); these have been identified in dinoflagellates by a number of studies [15-18]. Although it was long assumed that histone proteins are entirely absent from dinoflagellates, a number of recent reports have cast doubts on this idea, identifying relevant genes in a number of different species, including species of Gambierdiscus [19], A. catenella [20] and Symbiodinium minutum [21], species of Lingulodinium [22], and other species of Symbiodinium [23], as well as in environmental transcriptomes [24]. Another recent report identified dinoflagellate viral nucleoproteins (DVNPs), which differ markedly from histones, in dinoflagellates [40]. Although these workers argued that DVNPs function as histone substitutes, they also provided the first confirmation of expressed histone proteins in any dinoflagellate by detecting H2A peptides.

In the present study, we analyzed the expression profile of histone at the mRNA and protein levels in A. pacificum. Such insights can provide information about the functional role of histones in dinoflagellates. Transcriptome data of A. pacificum has allowed us detailed analysis of histone sequences and we identified and reported various linker, core, and histone-modifying genes. We first verified the presence of 10 different histone genes at the DNA and mRNA levels and then expression quantification of these genes was performed using real-time PCR analysis. Expression at the protein level was determined using commercially available antibodies raised against human histones or mass spectrometric (MS) analysis. The expression profile was analyzed under nutritionally stressed conditions, keeping in view that the availability of nitrogen and phosphorus is very crucial for photosynthetic dinoflagellates. Our results demonstrate that core histone gene expression was significantly increased during stress conditions, consistent with this hypothesis that histones may have a functional role in transcription regulation, especially during nutritional stress. This view is also supported by the presence of multiple histone-modifying enzymes. We were not able to detect histone expression at the protein level, and a histone-like protein was determined as a major nuclear component. Indepth analysis of histone protein sequences revealed that this species not only contains divergent types of histones but also the conventional histones. Despite the fact of histone gene presence, their sequence conservation, and active transcription within the cell, it is clear that histones are not the major nuclear proteins in dinoflagellates, suggesting an insubstantial role in DNA compaction.

\section{Materials and Methods}

\section{Algal Culture and Growth Conditions for Expression Analysis}

The culture of Alexandrium pacificum (A.tamarense species complex Group IV) used in this study was obtained from the Key Laboratory of Marine Genetics and Breeding, Ocean University of China, Ministry of Education, China. The culture was grown at $20 \pm 1{ }^{\circ} \mathrm{C}$ in an $\mathrm{f} / 2$ medium under a 12 -h light and 12-h dark photocycle [25] using cool white fluorescent lights with an intensity set at between 30 and $35 \mu \mathrm{mol}$ photon $\mathrm{m}^{-2} \mathrm{~s}^{-1}$ [26]. For molecular cloning and protein extraction, cells were grown in normal f/2 media and collected at the end of the ninth day following initial inoculation with a concentration of $2 \times 10^{6}$ cells $/ 1$. For quantitative $\mathrm{PCR}$, three samples from different growth conditions were used, following initial inoculation with $2 \times 10^{6}$ cells $/ 1$. The first of these growth conditions was log phase (LOP), in which cells were cultured for 11 days. Nutrient depleted conditions comprised low phosphorus (LP) and low nitrogen (LN). To produce these media, $4.8 \mu \mathrm{M} / 1$ phosphorus $\left(\mathrm{NaH}_{2} \mathrm{PO}_{4} \cdot 2 \mathrm{H}_{2} \mathrm{O}\right)$ or $76.8 \mu \mathrm{M} / 1$ nitrogen $\left(\mathrm{NaNO}_{3}\right)$ was added to $\mathrm{f} / 2$ medium. Finally, at 12:00 on the 11th day after initial inoculation, $5 \times 10^{6}$ cells were collected from the LOP culture and from the two nutrient-depleted cultures. Synchronized cultures were used in all cases [27].

\section{RNA Extraction and Complementary DNA (cDNA) Synthesis}

We extracted RNA using TRIzol reagent (Invitrogen, USA), following the manufacturer's instructions, and DNA digestion of extracted RNA was achieved using DNase-I (Takara, Japan). The quality and quantity of RNA were assessed using the NanoDrop2000 system (Thermo, USA); in all cases, $1 \mu \mathrm{g}$ of high-quality RNA (i.e., OD 260/280, 1.9-2.1) was used for cDNA synthesis and immediately stored at $-20^{\circ} \mathrm{C}$ for further use.

\section{PCR Amplification, Cloning, and Sequencing of Histone Genes}

Ten histone gene sequences were retrieved from the A. pacificum transcriptome (SRX368254); details of the genes and primers are provided in Table 1. Each unigene was then PCR-amplified, where the reaction mixture $(25 \mu \mathrm{l})$ included $10 \times$ PCR buffer $(2.5 \mu \mathrm{l})$, $\mathrm{MgCl}_{2}(1.5 \mu \mathrm{l})$, deoxynucleotide mix $(2.5 \mu \mathrm{l})$, forward and reverse primer $(1 \mu \mathrm{l}$ each), Taq DNA polymerase $(0.2 \mu \mathrm{l})$, template $(2 \mu \mathrm{l})$, and purified water $(14.3 \mu \mathrm{l})$. The PCR amplification program was set to denaturation at $94^{\circ} \mathrm{C}$ for $10 \mathrm{~min}$, annealing temperatures that ranged between $65^{\circ} \mathrm{C}$ and $68^{\circ} \mathrm{C}$ for $1 \mathrm{~min}$, followed by extension at $72^{\circ} \mathrm{C}$ for $1 \mathrm{~min}$. The PCR-amplified product was purified using an agarose gel purification kit. The purified products were cloned into a pMD18-T vector, and recombinants 
Table 1. Genes and primers used in this study for molecular cloning and expression analysis.

\begin{tabular}{|c|c|c|c|c|}
\hline $\begin{array}{l}\text { Gene } \\
\text { ID }\end{array}$ & $\begin{array}{l}\text { Gene name in the A. pacificum } \\
\text { transcriptome (SRX368254) }\end{array}$ & Purpose & Primers used, forward/reverse $\left(5^{\prime}-3^{\prime}\right)$ & $\begin{array}{l}\text { Product } \\
\text { (bp) }\end{array}$ \\
\hline \multirow[t]{4}{*}{ H2A.a } & Algae_064-1_Unigene_BMK.10533 & Cloning & GAAGGGCAGCCCGAAGAAGAAGC & 715 \\
\hline & & & GGCGAGCACGATCATGTGAGACA & \\
\hline & & RT-PCR & CGTGCTGCCGAACATCCACACA & 124 \\
\hline & & & TGCTCCATTCCGTCTCCTTTGC & \\
\hline \multirow[t]{4}{*}{ H2A.b } & Algae_064-3_Unigene_BMK.9977 & Cloning & TCATGGGAGACGGCCTCACGATC & 440 \\
\hline & & & CGTCAGCAGGGACTTGTCGATGTG & \\
\hline & & RT-PCR & GTCGCCAAGGACCTGAAGACCAAG & 142 \\
\hline & & & TCAGCAGGGACTTGTCGATGTGG & \\
\hline \multirow[t]{4}{*}{ H2B.a } & Algae_064-3_Unigene_BMK.33389 & Cloning & ACCAGAGCCCCATCCTCATTTAGT & 448 \\
\hline & & & CTCTTGGCAAGCACAGTCACCCTC & \\
\hline & & RT-PCR & CCAAAGCGGACAAAGAAGAGGA & 124 \\
\hline & & & CGGTGACACAGGACTCCATGAC & \\
\hline \multirow[t]{4}{*}{ H2B.b } & Algae_064-2_Unigene_BMK.13294 & Cloning & AAAAGAGGCGATGATTGCAGACT & 427 \\
\hline & & & GAGCGGCATCTTGGCGTACTTG & \\
\hline & & RT-PCR & CAGATTCACCCAGAGTGTGGCATT & 124 \\
\hline & & & TCCGTCTCTTCATGGTCCTTAACA & \\
\hline \multirow[t]{4}{*}{ H3.a } & Algae_064-1_Unigene_BMK.42014 & Cloning & TCGCTCATCATCCGCTGTCCCTTA & 428 \\
\hline & & & ATCGTGACCCGCTTGGCATGTATC & \\
\hline & & RT-PCR & CACGGACCTTCTCATTCGCAAAC & 101 \\
\hline & & & CAAGCACAGCCTGGGATTGGAAC & \\
\hline \multirow[t]{4}{*}{ H3.b } & Algae_064-1_Unigene_BMK.10241 & Cloning & AGATCATGCACTACCGCAAGACCA & 526 \\
\hline & & & ATACATATACACAGCAGCTTCGCC & \\
\hline & & RT-PCR & CTTCGAGGACGCCAACCTCTGC & 125 \\
\hline & & & TGCGACGACACCCCCTTTACCC & \\
\hline \multirow[t]{4}{*}{ H4.a } & Algae_0641_Unigene_BMK.40313 & Cloning & AACGGCTGGGCCAACCATGTCTT & 439 \\
\hline & & & ATCCACAAACСССССАТСССТCG & \\
\hline & & RT-PCR & CGCAGGAAGACGGTCACGGCACT & 135 \\
\hline & & & GTCACTCACCCGCAGCCCTCCAC & \\
\hline \multirow[t]{4}{*}{ H4.b } & Algae_064-2_Unigene_BMK.7539 & Cloning & TCCAAGGGCGACAAGTTCAGCAAG & 407 \\
\hline & & & CAGCACCCGGAAAGTTAAACGATG & \\
\hline & & RT-PCR & AGGGCGACAAGTTCAGCAAGGAG & 108 \\
\hline & & & CAGGCTTGGTGATGCCCGAGAT & \\
\hline \multirow[t]{4}{*}{ H1.a } & Algae_064-1_Unigene_BMK.29547 & Cloning & AGGGAGGAGTTAGTGGACAAGTGC & 390 \\
\hline & & & CTGGAGATCCGTGAGCGAGTAGG & \\
\hline & & RT-PCR & GCTCAAGGACCCTGCCATCTTT & 159 \\
\hline & & & ACTACCGGCTTTGCTTTCCCTTTA & \\
\hline \multirow[t]{2}{*}{ H1.b } & Algae_064-3_Unigene_BMK.36228 & Cloning & TCCACGCCTGCTGTTTGGTCTC & 403 \\
\hline & & & GCTTCCTTGGTCGGTGTTGCTG & \\
\hline \multirow[t]{2}{*}{ Control } & $\mathrm{GAPDH}^{\mathrm{a}}$ & RT-PCR & GACGGTGACTCCCTGGTGATTG & 152 \\
\hline & & & TTCAAGTGCGGCTGCACCTTTT & \\
\hline \multirow[t]{2}{*}{ Control } & Actin $^{a}$ & RT-PCR & TCGCGTTGTATTCTTGTTGTAGCC & 197 \\
\hline & & & TCGTCGCCGATGTAACTGTCCT & \\
\hline
\end{tabular}

${ }^{\mathrm{a}}$ Reference primer sequences were previously validated by our group (unpublished data).

with inserted genes were tested using colony PCR. All sequencing was completed at Beijing Genomic Institute, China; the generated sequences were then analyzed by alignment with a corresponding sequence from the transcriptome data. 


\section{Relative Quantification of Gene Expression Using Quantitative RT-PCR}

We selected nine histone genes for RT-qPCR using a Roche LightCycler 480 system; details of each gene and primer are presented in Table 1. All the selected genes were cloned using a pMD18-T vector, and 10-fold serial dilutions were prepared in each case in order to get a standard curve. The reaction mixture $(20 \mu \mathrm{l})$ included SYBR Premix $(10 \mu \mathrm{l})$, forward and reverse primer (0.5 $\mu \mathrm{l}$ each), purified $\mathrm{H}_{2} \mathrm{O}(7.2 \mu \mathrm{l})$, and $2 \mu \mathrm{l}$ of cDNA. The RTqPCR amplification program was set to denaturation at $95^{\circ} \mathrm{C}$ for $5 \mathrm{~min}$ followed by 40 cycles of denaturation at $95^{\circ} \mathrm{C}$ for $10 \mathrm{sec}$ and annealing at $60^{\circ} \mathrm{C}$ for $1 \mathrm{~min}$.

We performed expression analyses for the three growth conditions (i.e., LOP, LP and LN). The glyceraldehyde-3-phosphate dehydrogenase and actin genes were used as references/internal control, while the LOP was used as the control condition. We used the comparative threshold $\left(2^{-\Delta \Delta C t}\right)$ method to calculate fold change [28], and the standard error (SE) and mean Ct values were calculated for each condition and gene; a change in gene expression was considered significant when the expression was increased more than 2-fold (i.e., upregulated) or decreased to less than 0.5-fold (i.e., downregulated) [29].

Acid Extraction of Histone Proteins and Sodium Dodecyl Sulfate (SDS)-Polyacrylamide Gel Electrophoresis (PAGE) Analysis

The trichloroacetic acid (TCA) precipitation method was used to isolate histone proteins from the A. pacificum culture and from log phase of Saccharomyces cerevisiae (control) as described previously [22] but incorporating a few modifications. Cells were collected and suspended in $1 \mathrm{ml}$ of ice-cold acid extraction buffer (i.e., $1.5 \mathrm{mM} \mathrm{MgCl}_{2}, 10 \mathrm{mM}$ HEPES at $\mathrm{pH} 7.9,0.5 \mathrm{mM} \mathrm{DTT}, 10 \mathrm{mM}$ $\mathrm{KCl}, 1.5 \mathrm{mM}$ phenylmethylsulfonyl fluoride, and $0.25 \mathrm{M} \mathrm{HCl}$ ), disrupted using a bead beater, and incubated with stirring for $1 \mathrm{~h}$ on ice. The resultant cell lysate was then centrifuged at $11,000 \times g$ for $10 \mathrm{~min}$ at $4^{\circ} \mathrm{C}$, the supernatant was collected, and $100 \%$ TCA was added to obtain a final concentration of $33 \%(\mathrm{w} / \mathrm{v}) \mathrm{TCA}$. This solution was then incubated at $4^{\circ} \mathrm{C}$ for at least $3 \mathrm{~h}$ and acid-soluble proteins (ASPs) were obtained by centrifugation at $16,000 \times g$ for $15 \mathrm{~min}$ at $4^{\circ} \mathrm{C}$. The pellet was retained, washed twice with cold acetone, and dissolved in $100 \mu \mathrm{l}$ of double-distilled $\mathrm{H}_{2} \mathrm{O}$. Quantification was then performed using a Bradford assay [30].

Extracted ASPs were resolved using 15\% SDS-PAGE analysis as described previously [31].

\section{Immunodetection of Core Histones}

We performed western blot analysis using commercial rabbit polyclonal antibodies against human histones (i.e., H3-D124055 and H4-D222482; Sangon, China). We ran this test simultaneously for A. pacificum and S. cerevisiae ASPs; proteins from the gels were transferred to a polyvinyl difluoride membrane using a semi-dry electrophoretic transfer cell (Bio-Rad, USA), and horseradish peroxidase-conjugated goat anti-rabbit IgG was used as the secondary antibody. Following the addition of chemiluminescent substrate (ECL-C510043; Sangon, China), the membrane was exposed to a chemiluminescent imaging system (MiniChemi, China).

\section{MS Analysis}

We resolved $30 \mu \mathrm{l}$ of $A$. pacificum total acid-extracted protein on a $15 \%$ gel and the most prominent band (approx. $15 \mathrm{kDa}$ ) was excised from the gel and analyzed using matrix-assisted laser desorption/ionization time-of-flight MS (MALDI-TOF-MS). Destaining of the band, tryptic digestion, and MS analyses were all performed at Sangon, China.

\section{Sequence Analysis}

Histone gene sequences retrieved from A. pacificum trancriptome data were confirmed using a combination of BLAST searches on NCBI and Swissprot. A number of sequences were downloaded for alignment purposes, and multiple alignments were carried out using the software MUSCLE [32], visualized using JalView [33]. The physiochemical properties of the proteins were determined using resources at http://web.expasy.org/protparam [34], and conserved domains were predicted using resources at https:// www.ebi.ac.uk/interpro [35] and http://pfam.xfam.org [36]. Secondary structures of core histones were determined using an online resource (Phyr2) by putting the whole-gene-deduced protein sequence into the search box following the default settings (http://www.sbg.bio.ic.ac.uk/phyre2) [37].

\section{Results}

\section{Genes for Linker Histones, Core Histones, and Histone-} Modifying Enzymes Are Present in A. pacificum

We identified gene sequences for all core and linker histones in the A. pacificum transcriptome (SRX368254) (Table 2). Although we identified 31 unigenes for histone $\mathrm{H} 1$, none was a complete gene sequence; among core histones, we identified three unigenes for H2A (two full gene sequences), two unigenes for $\mathrm{H} 2 \mathrm{~B}$ (both comprised full gene sequences), 15 unigenes for $\mathrm{H} 3$ (two full genes sequences), and six unigenes for $\mathrm{H} 4$ (three full gene sequences).

A number of genes responsible for histone modification, chromatin formation, and remodeling are also present in A. pacificum, including histone acetyltransferases and deacetylases, methylases and demethylases, reader domains,

Table 2. Histone sequences detected in $A$. pacificum transcriptome data (SRX368254).

\begin{tabular}{cccccccccc}
\hline \multicolumn{3}{c}{$\begin{array}{c}\text { Total genes retrieved from } \\
\text { transcriptome data }\end{array}$} & \multicolumn{5}{c}{$\begin{array}{c}\text { Complete gene sequences } \\
\text { in the dataset }\end{array}$} \\
\hline H1 & H2A & H2B & H3 & H4 & H1 & H2A & H2B & H3 & H4 \\
31 & 3 & 2 & 15 & 6 & 0 & 2 & 2 & 2 & 3 \\
\hline
\end{tabular}


Table 3. Identification of $A$. pacificum sequences responsible for histone modification, chromatin formation, and remodeling.

\begin{tabular}{|c|c|c|c|c|}
\hline Category & Family/Domain & Unigenes & Biological role & Reference \\
\hline \multirow[t]{3}{*}{ Histone acetyltranferases } & GNAT & 85 & \multirow{3}{*}{$\begin{array}{l}\text { Acetylates conserved lysine amino acids } \\
\text { linked to transcriptional activation }\end{array}$} & \multirow[t]{3}{*}{ [64] } \\
\hline & MYST & 0 & & \\
\hline & Nuclear receptor coactivator & 1 & & \\
\hline \multirow[t]{2}{*}{ Histone deacetylases } & Histone deacetylase & 13 & \multirow[t]{2}{*}{ Removes acetylation marks } & \multirow[t]{2}{*}{ [65] } \\
\hline & Sir2 & 21 & & \\
\hline \multirow[t]{2}{*}{ Histone methyltransferases (HMT) } & SET & 16 & \multirow{2}{*}{$\begin{array}{l}\text { Transfers methyl groups; methylated histones } \\
\text { can repress or activate transcription }\end{array}$} & \multirow[t]{2}{*}{ [66] } \\
\hline & Dot1 & 26 & & \\
\hline (lysine specific) & Unclassified & 5 & & \\
\hline \multicolumn{5}{|l|}{ HMT } \\
\hline (arginine specific) & PRMT5 & 4 & & \\
\hline \multirow[t]{2}{*}{ Histone demethylase } & Lysin specific & 3 & \multirow{2}{*}{$\begin{array}{l}\text { Removes methyl group from histone and } \\
\text { regulates gene expression }\end{array}$} & \multirow[t]{2}{*}{ [67] } \\
\hline & Arginine specific & 4 & & \\
\hline \multirow[t]{6}{*}{ Reader domain } & Bromodomain & 13 & \multirow{6}{*}{$\begin{array}{l}\text { Proteins that recognize specific marks on } \\
\text { histone proteins }\end{array}$} & \multirow[t]{6}{*}{ [68] } \\
\hline & Chromodomain & 17 & & \\
\hline & $\mathrm{PhD}$ & 11 & & \\
\hline & TUDOR & 29 & & \\
\hline & PWWP & 1 & & \\
\hline & WD40 & 543 & & \\
\hline \multirow[t]{6}{*}{ Chromatin remodeling } & SNF2 & 120 & \multirow{6}{*}{$\begin{array}{l}\text { Allows regulatory transcription machinery } \\
\text { proteins to access condensed DNA }\end{array}$} & \multirow[t]{6}{*}{ [69] } \\
\hline & SLIDE & 0 & & \\
\hline & SnAC & 0 & & \\
\hline & DBINO & 0 & & \\
\hline & SWIB & 1 & & \\
\hline & SWIRM & 0 & & \\
\hline \multirow[t]{3}{*}{ Facilitates chromatin transcription } & FACT-spt-16 & 1 & \multirow{3}{*}{$\begin{array}{l}\text { Role in transcription through chromatinized } \\
\text { DNA }\end{array}$} & \multirow[t]{3}{*}{ [70] } \\
\hline & SPT 16 & 1 & & \\
\hline & SSRP1 & 1 & & \\
\hline \multirow[t]{4}{*}{ Histone chaperones } & ASF1 & 1 & \multirow{4}{*}{$\begin{array}{l}\text { Binds histones and regulates nucleosome } \\
\text { assembly }\end{array}$} & \multirow[t]{4}{*}{ [71] } \\
\hline & CAF-1 & 0 & & \\
\hline & Hira & 10 & & \\
\hline & NAP & 3 & & \\
\hline
\end{tabular}

Families and domains listed above were selected from Marinov and Lynch [45].

FACT (facilitates chromatin transcription) complex, and histone chaperones (Table 3). Histone acetyltranferases (HATs) have multiple families including the GNAT-type HAT family, MYST, nuclear receptor coactivator, and others. Results showed that A. pacificum expresses more numbers of sequences for the GNAT family (85) compared with other families within this group. Indeed, of the two classes of histone lysine methyltransferases (HMTs) identified, the majority belonged to the DOT1 domain class (26) as opposed to the SET class (16). Four classes of histone deacetylases (HDACs) are known [38]; classes I, II, and IV are characterized by a histone deacetylase domain and class III is characterized by the presence of a SIR2 domain. Twenty-one unigenes identified as having a SIR2 domain and 13 unigenes belonged to other classes. WD40 was the most abundant of the reader domains; this binds to trimethylated lysine, amongst other substrates, and the presence of a complete FACT complex in A.pacificum shows that transcription through a nucleosome array does occur [39]. 
Table 4. Results of histone gene amplification using cDNA as template.

\begin{tabular}{ccccccl}
\hline Accession No. & Gene name & PCR product size (bp) & Gene status & ORF coverage & Intron $^{\text {a }}$ & \multicolumn{1}{c}{ Gene [Species hit] } \\
\hline KY659046 & H1.a & 390 & Partial & - & - & H1 [Triticum aestivum] \\
KY659047 & H1.b & 403 & Partial & - & - & H1 [Pisum sativum] \\
KY659038 & H2A.a & 715 & Partial & $87 \%$ & Yes & H2A.X [Alexandrium tamarense] \\
KY659039 & H2A.b & 440 & Partial & $85 \%$ & Yes & H2A.Z [Anoplopoma fimbria] \\
KY659040 & H2B.a & 448 & Full & $100 \%$ & No & H2B [Dacryopinax primogenitus] \\
KY659041 & H2B.b & 427 & Partial & $99 \%$ & No & H2B [Babesia bovis] \\
KY659042 & H3.a & 428 & Partial & $83 \%$ & No & H3 [Eimeria maxima] \\
KY659043 & H3.b & 526 & Full & $100 \%$ & Yes & H3 [Chlamydomonas reinhardtii] \\
KY659044 & H4.a & 439 & Full & $100 \%$ & Yes & H4 [Tauraco erythrolophus] \\
KY659045 & H4.b & 407 & Partial & $91 \%$ & Yes & H4 [Zea mays] \\
\hline
\end{tabular}

ORF, open reading frame.

${ }^{a}$ Intron; while using DNA as a template.

\section{Amplification and Cloning of Variants of Histone Genes}

Our results show that a number of histone sequences are present in the A. pacificum transcriptome. Thus, to confirm whether or not these sequences are present in the organism, we amplified, cloned, and sequenced 10 genes (i.e., two for each core and linker histone) from cDNA (Table 4). All these sequences were the same as in the transcriptome data, although there were a small number of base changes in some genes. Using the same primer, we then amplified core histone genes from the DNA template; the results of this approach showed that the genes H2B.a, H2B.b, and H3.a lacked introns, whereas H3.b and both variants of $\mathrm{H} 2$ (A and B) contained intron sequences (Fig. 1). Linker histone genes were readily amplified using cDNA as the template; however, we were not able to amplify from DNA.

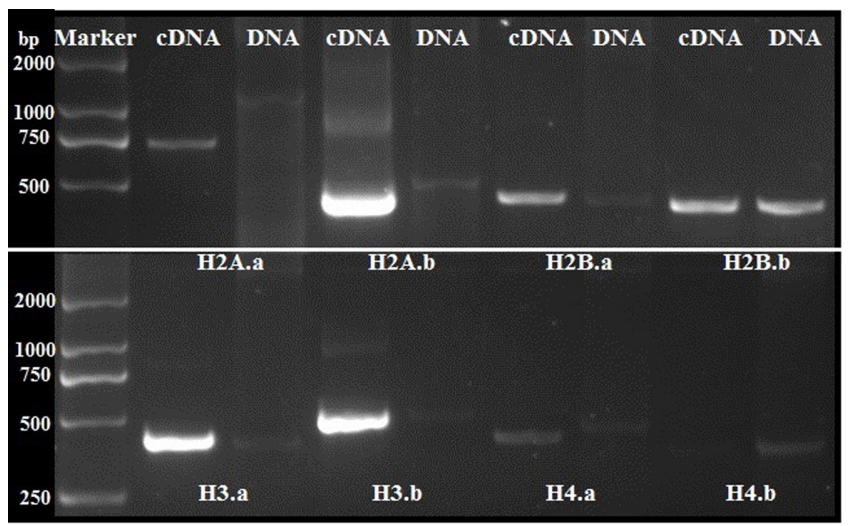

Fig. 1. Amplification of core histone genes from cDNA and DNA.

The core histone genes of Alexandrium pacificum were amplified from cDNA and DNA using the same primers.

\section{Histone Gene Relative Expression under Nutrient-Depleted} Cultures

Nine histone genes chosen for RT-qPCR analysis were amplified, cloned, and sequenced, and plasmids were extracted. We monitored the relative expression levels of histone genes under two nutrient-depleted conditions (LP and $\mathrm{LN}$ ) to determine the functional significance of A. pacificum histones. We carried out qPCR experiments on mid G-phase cultures. This species showed a significantly high expression of histone mRNA for histone genes under nitrogen stress, except H2B.a, H2B.b, and H1.a. Under phosphorus-limited cultures, histone genes H2A.a, H3.a, H3.b, and H4.b exhibited near stable expression, whereas H1.a, H2B.a, H2B.b, and H4.a were downregulated when compared with 11-day-old cultured cells. Significantly high expression was observed in the H2A.Z variant during phosphorus stress (Fig. 2).

\section{Protein-Level Histone Expression in A. pacificum}

To evaluate histone expression at the protein level, we employed a range of different sensitive techniques, including western blotting and MS. Acid-extracted proteins from logphase condition were resolved using SDS-PAGE and stained with Coomassie blue. Results from this approach showed that A. pacificum does not exhibit a typical pattern of histones on a gel as is the case, for example, in yeast (Fig. 2). In contrast, A. pacificum exhibited a very prominent and darkly stained band in the vicinity of $15 \mathrm{kDa}$, confirmed via MALDI-TOF-MS to correspond with a HLP with a molecular mass of $11.47 \mathrm{kDa}$. The reduced mobility of this protein on the gel is likely the result of the highly basic residues that it contains [40]. Immunoblotting was then performed using commercial antibodies of human origin against $\mathrm{H} 3$ and $\mathrm{H} 4$ 


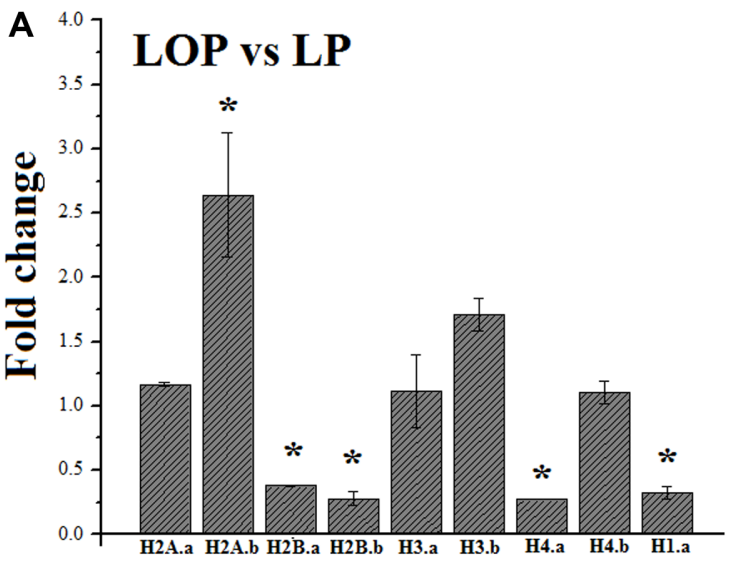

Histone genes

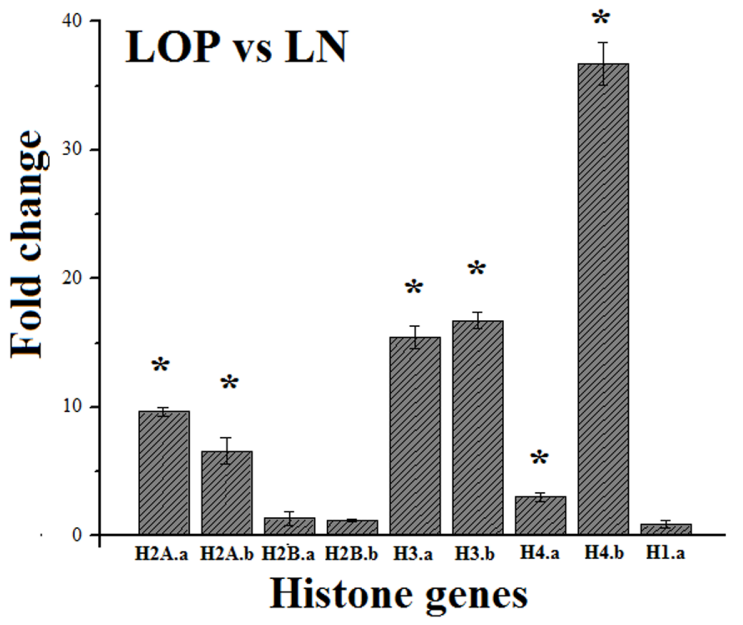

B
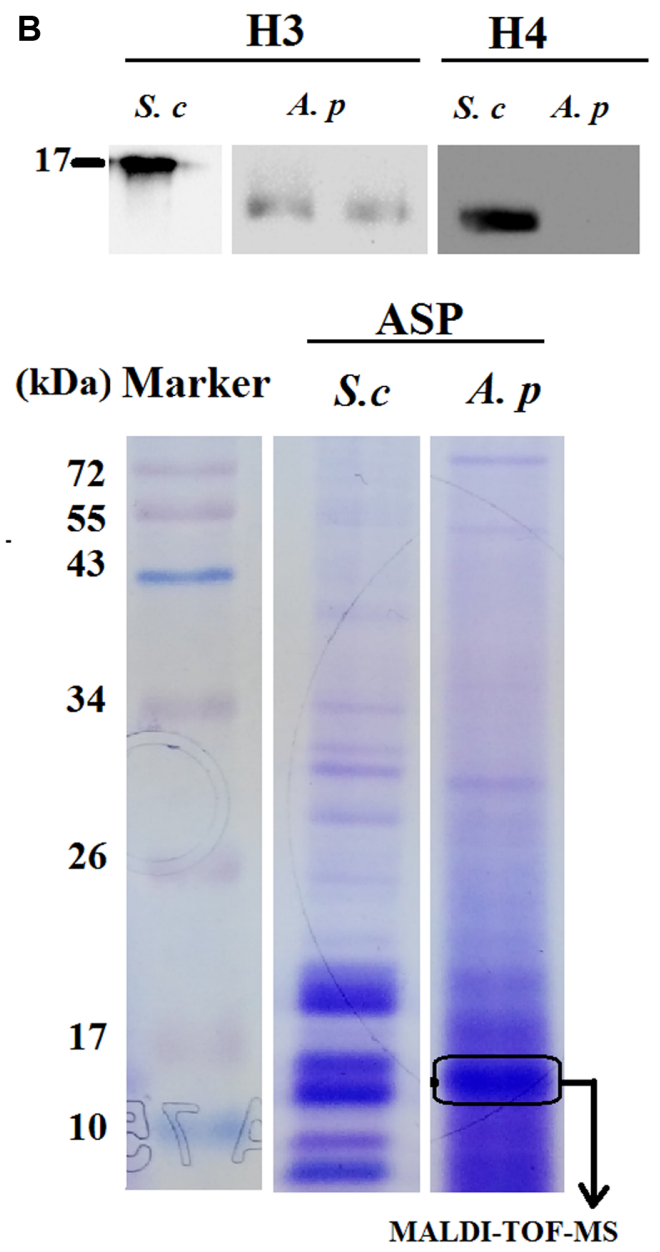

Fig. 2. Expression of A. pacificum histone genes in nutrient-depleted media and the protein level.

(A) Relative expression levels of A. pacificum histone genes under nutritional stress. A change in gene expression was considered significant when expression was increased more than 2-fold (i.e., upregulated) or decreased to less than 0.5-fold (i.e., downregulated). An asterisk $\left(^{*}\right)$ on the bar denotes significant difference in gene expression relative to the log phase. (B) Upper panel: Immunodetection of core histones in A. pacificum and yeast (S. cerevisiae, control). Acid-soluble proteins (ASP) from A. pacificum (A.p) and S. cerevisiae (S.c) were prepared for 15\% SDS-PAGE analysis and immunoblotting was performed using commercial antibodies against core histones. Both tested antibodies showed a positive reaction against yeast histones, whereas no signal was detected for A. pacificum, with the exception of the H3 gene. The identity of this band, however, remains unknown. Lower panel shows ASP from A. pacificum (A.p) and S. cerevisiae (S.c). The most prominent band near $15 \mathrm{kDa}$ was excised and subjected to analysis using MALDI-TOF-MS.

histones; this approach successfully detected yeast core histones and failed to detect core histones of A. pacificum, whereas antibodies against histone H3 strongly crossreacted with a protein of unknown identity that showed increased mobility (approx. $11 \mathrm{kDa}$ ) compared with the yeast histone $\mathrm{H3}$ (Fig. 2).

\section{A. pacificum Histones Show Sequence Divergence Compared with Other Eukaryotes}

The results of this study showed that $A$. pacificum possesses multiple histone gene transcripts with sequences that are divergent compared with other eukaryotes. Some regions are conserved, however, including the histone fold region. At the same time, the $\mathrm{N}$-termini of most proteins exhibit divergence and additional sequences that elongate the N-terminal region. Because a number of start codons were found in open reading frames (ORFs), we predicted this section of the sequence (Fig. 3) by aligning A. pacificum histone protein sequences with those of other species. The results of this comparison showed that the extra start codons before the actual starting position do not belong to a conserved domain and share no sequence similarity with 


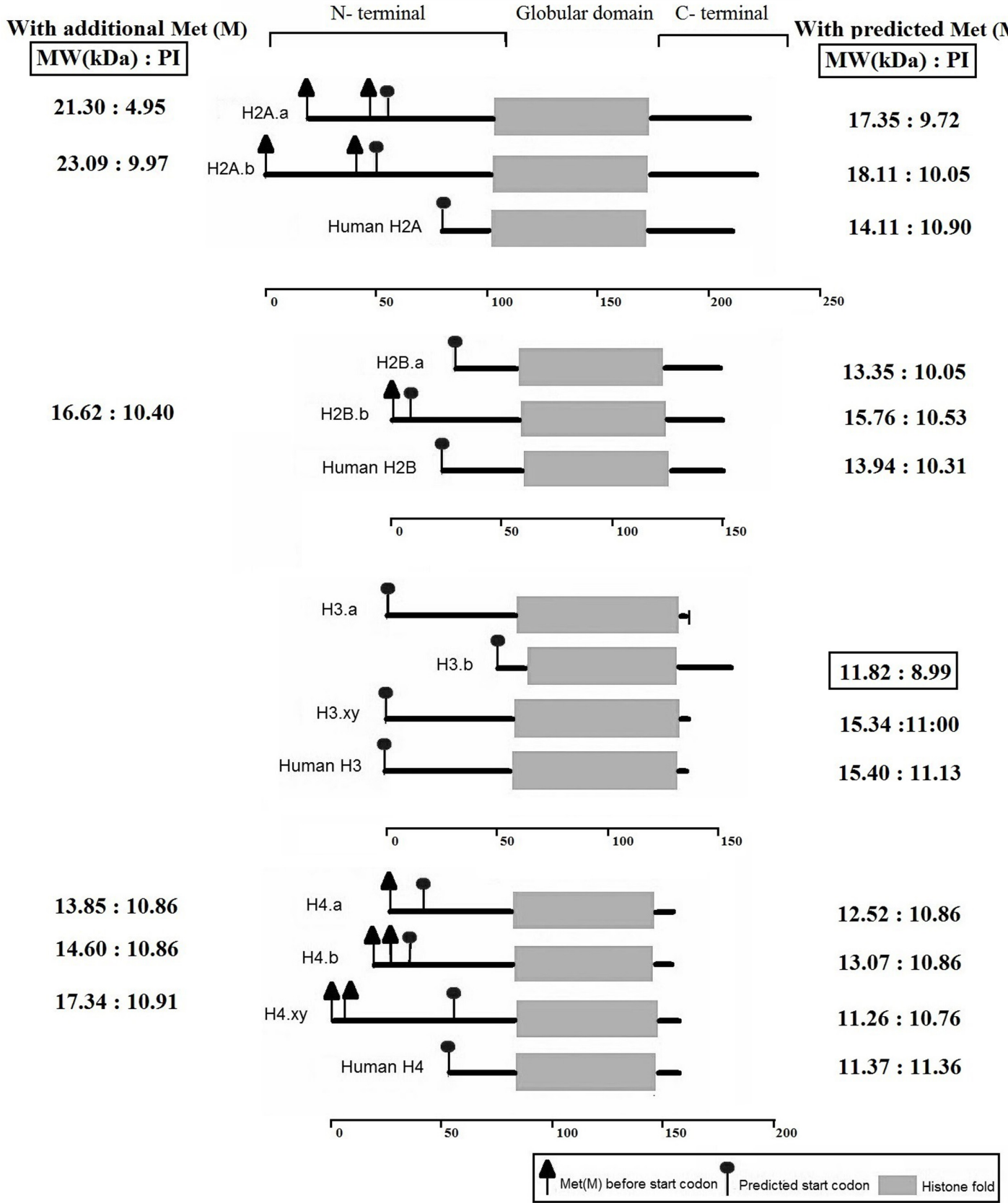

Fig. 3. Histone protein domains and start codon predictions for A. pacificum and human core histones.

Because more than one methionine/start codon (triangle) was present at the start of each ORF, one was predicted as the most probable start codon (circle) following alignment of the A. pacificum histone sequences with those of other species.

other species. Indeed, the $\mathrm{H} 2 \mathrm{~A}$ and $\mathrm{H} 4$ gene sequences contained two additional start codons in their ORFs that rendered them more elongated than conventional histones, whereas two $\mathrm{H} 3$ sequences have just one start codon and lengths that are the same as human H3. One H3 (H3.b) comprised a full-length gene, albeit markedly smaller than conventional histone $\mathrm{H} 3$, with the smallest $\mathrm{N}$-terminal tail in the group. Similarly, the H1 sequences of A. pacificum were the most divergent and had very little sequence similarity with other eukaryotes. The molecular characteristics of A. pacificum and human histones are shown in Table 5; these data showed that the highest variation in protein length is in H2A compared with the human protein. The GC contents of histone genes in dinoflagellates range 
Table 5. Molecular characterization of histone genes in A. pacificum and humans.

\begin{tabular}{|c|c|c|c|c|c|c|c|c|c|}
\hline Gene ID & $\begin{array}{l}\text { ORF } \\
\text { length }\end{array}$ & $\begin{array}{l}\text { Stop } \\
\text { codon }\end{array}$ & GC\% & $\begin{array}{l}\text { Peptide } \\
\text { residues }\end{array}$ & $\begin{array}{l}\mathrm{Mw} \\
(\mathrm{kDa})\end{array}$ & PI & $\begin{array}{c}\text { Acidic } \\
\text { amino acid }\end{array}$ & $\begin{array}{c}\text { Basic } \\
\text { amino acid }\end{array}$ & $\begin{array}{l}\text { Most abundant } \\
\text { amino acid }\end{array}$ \\
\hline H2A.a & 489 & TGA & 62 & 162 & 17.35 & 9.72 & 18 & 27 & Lys \\
\hline H2A.b & 513 & TGA & 64 & 170 & 18.11 & 10.05 & 18 & 35 & Lys \\
\hline H2B.a & 360 & TGA & 56 & 119 & 13.35 & 10.05 & 11 & 25 & Lys \\
\hline H2B.b & 423 & TGA & 56 & 140 & 15.76 & 10.53 & 11 & 35 & Lys \\
\hline H3.b & 318 & TGA & 69 & 105 & 11.82 & 8.99 & 13 & 16 & Ala \\
\hline H3.xy & 411 & TGA & 64 & 136 & 15.34 & 11.00 & 11 & 29 & Ala \\
\hline H4.a & 339 & TAG & 60 & 112 & 12.52 & 10.86 & 10 & 26 & Arg \\
\hline H4.b & 357 & TGA & 64 & 118 & 13.07 & 10.86 & 10 & 26 & Arg \\
\hline H4.xy & 303 & TAG & 60 & 100 & 11.26 & 10.76 & 9 & 22 & Arg \\
\hline Human H2A & 393 & TAA & 63 & 130 & 14.11 & 10.90 & 9 & 26 & Ala/Leu \\
\hline Human H2B & 381 & TAA & 60 & 126 & 13.94 & 10.31 & 10 & 28 & Lys \\
\hline Human H3 & 411 & TAA & 60 & 136 & 15.40 & 11.13 & 11 & 31 & Ala/Arg \\
\hline Human H4 & 312 & TGA & 61 & 103 & 11.37 & 11.36 & 7 & 25 & Gly \\
\hline
\end{tabular}

Note that linker histones and the H3.a gene are not included in this table because they have incomplete ORFs. Two extra histone variants from the transcriptomes of A. pacificum, H3.xy (Algae_064-2_Unigene_BMK.1001) and H4.xy (Algae_064-1_Unigene_BMK.87970/68734), as well as human core histones sequences, were included for sequence analysis.

between $56 \%$ and $69 \%$, a larger span than that seen in humans, which are concentrated between $60 \%$ and $63 \%$. The highest GC content (69\%) was present in the gene H3.b, a typical dinoflagellate histone; indeed, the histones are highly basic proteins that comprise large numbers of basic amino acids (i.e., Lys+Arg). Data showed that Lys, Ala, and Arg are the most abundant amino acids present in the histones $\mathrm{H} 2 \mathrm{AB}, \mathrm{H} 3$, and $\mathrm{H} 4$ of $A$. pacificum, respectively. Although the highest PI value was seen in the human H4 histone (11.36), the most abundant amino acid encoded by

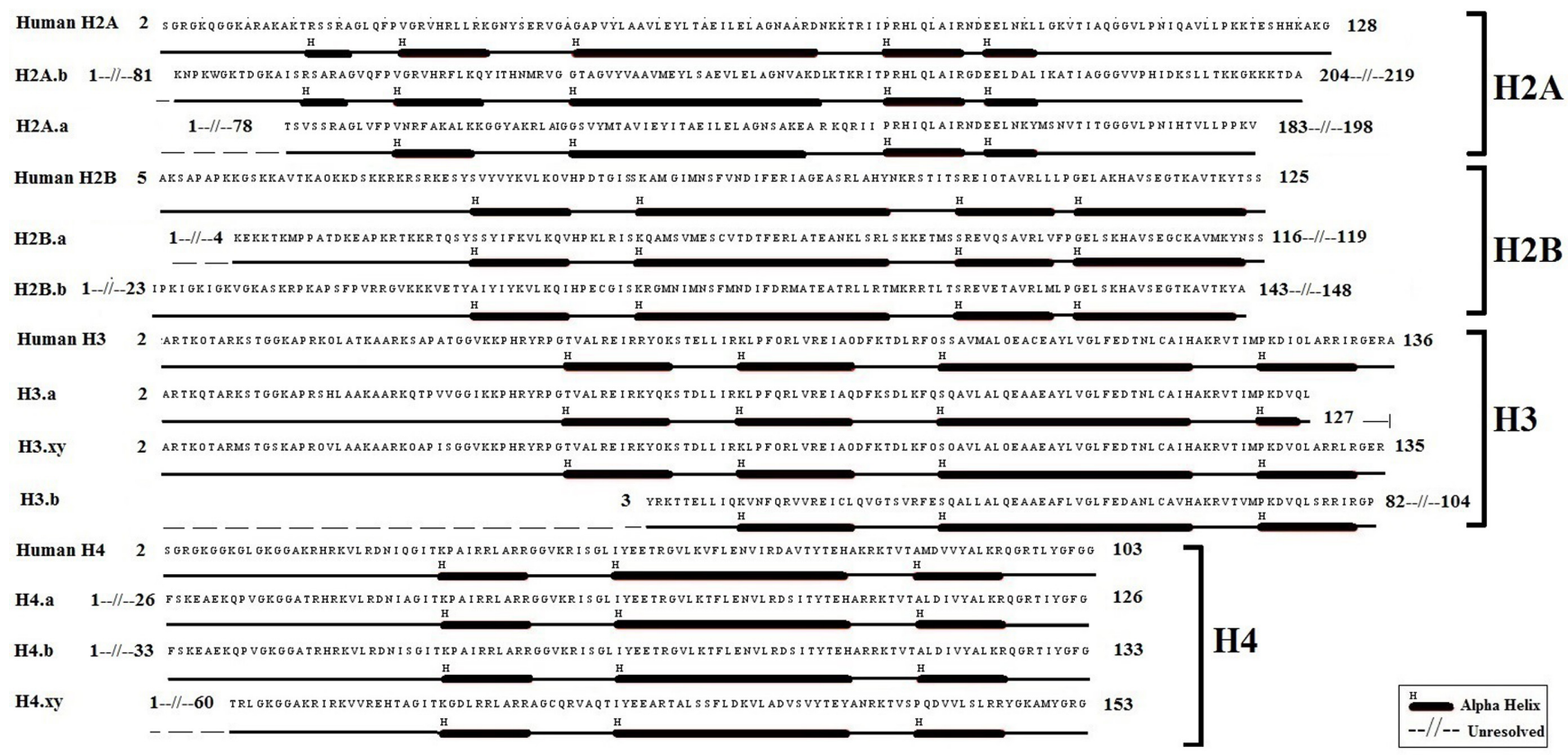

Fig. 4. Secondary structural predictions for the core histones of A. pacificum and humans.

These secondary structures were predicted using Phyr2, although extended histone tails could not be resolved by the software. 
this gene is Gly, rather than Lys or Arg (basic amino acids).

\section{Secondary Structure of Histone Proteins in A. pacificum: Comparison with Human Histones}

To gain insights into the structures of encoded proteins based on their sequences, we made secondary structural predictions. To do this, we predicted the secondary structures of A. pacificum and human core histones using the software Phyr2 (Fig. 4). Our results showed that the human H2A structure comprises five helices, and almost the same was predicted for the protein product of the A. pacificum H2A.b gene; however, the product of H2A.a has four helices in its secondary structure. Similarly, the proteins encoded by the human $\mathrm{H} 2 \mathrm{~B}$ and $\mathrm{H} 3$ genes both have four helices in their structures, very similar to the situation in A. pacificum, with the exception of H3.b. In contrast, the structure of the human $\mathrm{H} 4$ gene product comprises three helices, identical to those seen in all $\mathrm{H} 4$ variants. The most conserved and normal length protein sequences were observed for $\mathrm{H} 3$, whereas $\mathrm{H} 2 \mathrm{~A}$ contained the most extended sequences. Extended $\mathrm{N}$ and $\mathrm{C}$ termini were unable to be resolved by the software because no conserved or additional domains were present in it.

\section{Discussion}

\section{Conservation and Divergence of Dinoflagellate Histone Proteins}

Dinoflagellates are divergent from other eukaryotes because they do not have nucleosomal chromatin organization [41]. Indeed, with the exception of two groups, their basic nuclear proteins do not show typical histone patterns on gels [42]. Exceptions to this are the binucleate dinoflagellates (e.g., Peridinium balticum) that possess typical eukaryote and dinoflagellate nuclei [43], and Perkinsus marinus, which has a nucleus that resembles a typical eukaryotic cell [44]. This species also possesses both linker and core histone proteins [40], but lacks HLPs, the major nuclear proteins in core dinoflagellates.

One outcome of this study is the revelation that $A$. pacificum expresses all core and linker histones, as well as a number of histone modification enzymes. To resolve potential conflict and determine whether or not the detected histone sequences belong to dinoflagellate species, we present two observations. In the first one, histone sequences obtained from the transcriptomes of dinoflagellates exhibit a level of sequence divergence that makes them unique, and secondly, both axenic and non-axenic dinoflagellate cultures contain histones [45]. The largest number of histone genes was observed in the transcriptomes of "dinotom" dinoflagellates, so-called because they possess both dinoflagellate and diatom nuclei, as they harbor a tertiary endosymbiont of the latter [46]. Although we observed elongated histone sequences in the transcriptome data, many sequences of normal length were also observed in A. pacificum. An elongated histone tail in A. pacificum does not mean that additional protein domains are necessarily present, as only a core histone domain was identified. However, some dinoflagellates do possess additional domains, including the TRAM-LAGI-CLN8 and NAD(P) binding domains in $\mathrm{H} 2 \mathrm{~A}$ [45]. The role of these additional domains remains unclear.

Overall, based on the molecular characterization of core histones, it is clear that $\mathrm{H} 3$ genes are the most conserved in A. pacificum, whereas the lowest degree of conservation is seen in H2A. This might present one explanation as to why human origin antibodies can readily detect dinoflagellate $\mathrm{H} 3$ proteins after immunoblotting.

Histone modification enables the performance of several functions, including transcriptional initiation and chromatin dynamics, that are linked to epigenetic regulation [47]. A. pacificum, for example, expresses a number of proteins that act as chromatin mark readers, writers, and erasers.

This species possesses a large number of acetyltransferases, deacetylases, methylases, demethylases, and histone chaperones; their presence corroborates a role for histones in the regulation of gene expression.

\section{Expression Control and Management of Histone Proteins}

It is generally accepted that canonical histone proteins are encoded by replication-dependent (RD) genes, the only known eukaryotic mRNAs that contain a conserved stemloop at the $3^{\prime}$ end instead of a polyA tail $[3,48]$. These RD mRNAs are expressed in high concentrations during the Sphase of the cell cycle (expression increases 35-fold during this phase), decreasing rapidly towards the end of this phase $[3,49]$. The synthesis of variants known as replicationindependent (RI) histones or polyadenylated mRNAs persists outside of the S-phase [48]. Our recent study (unpublished data) showed that expression of histone genes remain stable during the G and S phases of the cell cycle. Although we hypothesized the presence of a distinct mechanism in dinoflagellates to control the expression of histones, no data are presently available. Expression analysis of histone mRNAs has so far only been completed using transcriptome data, which are limited owing to the absence of a polyA tail 
in RD histones [48].

To date, some RD histone genes have been identified that remain active and encode mRNAs during the $G$ phase, even when cells are no longer in a dividing state [3]. For example, H2A.X exhibits characteristics of both RD and RI histone genes and produces adenylated and non-adenylated mRNAs. At the same time, H2A.X mRNAs and proteins are synthesized throughout the cell cycle [50]. Our results showed that variants of histone genes are expressed in A. pacificum (Table 4). H2A. An X-type variant plays a significant role in DNA damage repair in other eukaryotes. In the present study, H2A.a maintained a steady level of transcription in phosphorus-limited culture during the $\mathrm{G}$ phase while histone H2A.b expression was significantly upregulated. The H2A.Z variant has been previously proposed to regulate transcription in many eukaryotes in a number of ways, especially during phosphate stress [51] and other stress conditions [52]. Under the limited availability of phosphorus, dinoflagellates stop their cell division as an adaptive mechanism [53]. Similarly, in nitrogen-depleted culture, dinoflagellate cells slow down or stop their cell division. Nitrogen availability is very important for dinoflagellate growth, especially for toxin production. In reduced cell division, higher expression of histone genes indicates their role during stress management in cells, possibly by controlling transcription.

Histone hairpin-binding protein or stem-loop-binding protein (SLBP) specifically binds to RD histone's conserved stem loop and helps in mRNA transport, stability, and translation regulation [54]. Five unigenes encoding SLBP were detected in the A. pacificum trancriptome; however, none of the histone gene sequences contain conserved motif in $3^{\prime}$ UTR that can compose a conserved stem loop. There could be two possibilities for this. First, most of the histone sequences are not represented completely in the transcriptome; and second, deep-sequencing techniques are based on the polyA tail section, so there is little information about the transcripts that lack a polyA tail, such as RD histones [55]. Instead of a conserved stem loop sequence, conserved $3^{\prime}$ UTR sequence motifs (Brd-box (AGCUUUA) (in H2B.a) and K-box (cUGUGAUa) (in H3Algae_064-2_Unigene_BMK.91286)) were detected. These conserved motifs in $3^{\prime}$ UTR negatively regulate the transcription of notch target genes, and any mutation in it can lead to overexpression of protein as reported previously in Drosophila [56]; however, the function of these motifs in A. pacificum is unclear.

In A. pacificum, histone expression at the protein level is very little; however, the presence of high expression of histone mRNA is not surprising. Cells have a strict regulatory mechanism at the translation and post translational levels because of lethal effects of unbound histones in the cell. Positively charged histone proteins can attach nonspecifically to negatively charged DNA and other cellular bodies and hamper their function [57]. Histone chaperones (HIRA family) control histone gene expression and repress the expression of histone genes not only in $G$ phase but also in $S$ phase, and overexpression of HIRA proteins leads to repression of histone genes in humans [58]. The FACT complex in yeast also prevents the accumulation of transcription evicted histones [59]. SLBPs control the translation of histone mRNA, and DNA checkpoint proteins degrade the unbound/excess histone protein [60]. Eight unigenes for DNA checkpoint proteins were identified in A. pacificum from the transcriptome data. Although histones are quite stable proteins, with a half-life of 4-5 months [61], unbound histone proteins are rapidly degraded with the half-life of $30-40 \mathrm{~min}$ in yeast [62]. Thus, it is equally possible that either A. pacificum strictly inhibits the excess translation of histone mRNA or rapidly degrades the unbound histone proteins owing to their limited role in DNA packaging.

We were unable to detect histone proteins even when using a range of different sensitive techniques, including immunoblotting and MS analysis. Immunogens used to generate antibodies against $\mathrm{H3}$ and $\mathrm{H} 4$ shared 88\% sequence similarity; still, no positive reaction was observed in this report. Our species $\mathrm{H} 3$ and $\mathrm{H} 4$ sequences are highly conserved with other eukaryotes, so a negative reaction strongly indicates very little expression of histone proteins in dinoflagellates. In addition, our results showed that antibodies against the histone $\mathrm{H} 3$ protein cross-react with a protein of unknown identity; we refer to this as the A. pacificum histone $\mathrm{H} 3$ because one variant in A. pacificum (H3.b) has a molecular mass of $11.89 \mathrm{kDa}$ (Table 5). The greatest degree of similarity that was observed between different variants of this gene supports our hypothesis that this reduced-sized band was correctly identified. We were unable to detect the H3 protein using MS because lessabundant proteins are often masked by more abundant ones in samples [63]. In any case, histone expression at the protein level is very limited in dinoflagellates. In dinoflagellates, only $0.2 \%$ of the genome is transcriptionally active. Hence, even if very low amounts of histone proteins are present in dinoflagellates, they can still regulate transcription. 


\section{A. pacificum Major Basic Nuclear Proteins}

Although histone proteins are responsible for DNA compaction in other eukaryotes, this appears not to be the case for dinoflagellates. Previous studies have identified HLPs in dinoflagellates, and a novel DNA-binding protein called DVNP has recently been identified in this protist. Core dinoflagellate species even contain both HLPs and DVNP (e.g., Alexandrium and species of Lingulodinium). A. monilatum possesses 38 unigenes for DVNPs, the highest number amongst dinoflagellate species studied to date [45]. DVNP unigenes were also detected in the A. pacificum transcriptome. The results of this study show that HLP is present in A. pacificum as a major nuclear protein. Interestingly, in A. pacificum only two variants of HLPs are present; however, the transcript abundance of HLP is nearly 300 times more than the histone transcripts (HLP: RPKM 11,795; and histones: RPKM 5-37). Of note, genes for histones, HLPs, and DVNPs are present in A. pacificum but expression at the protein level is only detectable for HLPs to date. DVNP and histone protein expression levels need more precise techniques to measure their low levels.

The presence of different histone and histone-modifying gene sequences, conservation of the core histone domain, and reasonably high transcript level of histones during stress all strongly suggest that histones are not only present in dinoflagellates, but also have functional significance. Advanced techniques for protein extraction and detection are required to measure the low histone levels seen in dinoflagellates. Although these are not the major nuclear proteins in A. pacificum, the functional significance of histones cannot be underestimated, and further work will be required to investigate their importance in dinoflagellate biology.

\section{Acknowledgment}

This work was funded by the National Natural Science Foundation of China (41676091; 41176098).

\section{Conflict of Interest}

The authors have no financial conflicts of interest to declare.

\section{References}

1. Over RS, Michaels SD. 2014. Open and closed: the roles of linker histones in plants and animals. Mol. Plant 7: 481-491.

2. Luger K, Mäder AW, Richmond RK, Sargent DF, Richmond TJ.
1997. Crystal structure of the nucleosome core particle at $2.8 \AA$ A resolution. Nature 389: 251-260.

3. Lyons SM, Cunningham $\mathrm{CH}$, Welch JD, Groh B, Guo AY, Wei B, et al. 2016. A subset of replication-dependent histone mRNAs are expressed as polyadenylated RNAs in terminally differentiated tissues. Nucleic Acids Res. 44: 9190-9205

4. Sournia A. 1995. Red tide and toxic marine phytoplankton of the world ocean: an inquiry into biodiversity, pp. 103-112. In: Proceedings of the 6th International Conference on Toxic Marine Phytoplankton, Harmful Marine Algal Blooms, 1993, Nantes, France. Lavoisier Publising/Intercept, Paris, France.

5. John U, Litaker RW, Montresor M, Murray S, Brosnahan ML, Anderson DM. 2014. Formal revision of the Alexandrium tamarense species complex (Dinophyceae) taxonomy: the introduction of five species with emphasis on molecularbased (rDNA) classification. Protist 165: 779-804.

6. Wang L, Zhuang Y, Zhang H, Lin X, Lin S. 2014. DNA barcoding species in Alexandrium tamarense complex using ITS and proposing designation of five species. Harmful Algae 31: 100-113.

7. Imai I, Yamaguchi M, Hori Y. 2006. Eutrophication and occurrences of harmful algal blooms in the Seto Inland Sea, Japan. Plankton Benthos Res. 1: 71-84.

8. Waller RF, Jackson CJ. 2009. Dinoflagellate mitochondrial genomes: stretching the rules of molecular biology. Bioessays 31: 237-245.

9. Barbrook A, Howe C. 2000. Minicircular plastid DNA in the dinoflagellate Amphidinium operculatum. Mol. Gen. Genet. 263: 152-158.

10. Dodge J. 1971. A dinoflagellate with both a mesocaryotic and a eucaryotic nucleus I. Fine structure of the nuclei. Protoplasma 73: 145-157.

11. Costas E, Goyanes V. 2005. Architecture and evolution of dinoflagellate chromosomes: an enigmatic origin. Cytogenet. Genome Res. 109: 268-275.

12. Shupe K, Rizzo PJ. 1983. Nuclease digestion of chromatin from the eukaryotic algae Olisthodiscus luteus, Peridinium balticum, and Crypthecodinium cohnii. J. Protozool. 30: 599-606.

13. Herzog M, Soyer M. 1981. Distinctive features of dinoflagellate chromatin. Absence of nucleosomes in a primitive species Prorocentrum micans E. Eur. J. Cell Biol. 23: 295-302.

14. Rill RL, Livolant F, Aldrich HC, Davidson MW. 1989. Electron microscopy of liquid crystalline DNA: direct evidence for cholesteric-like organization of DNA in dinoflagellate chromosomes. Chromosoma 98: 280-286.

15. Chan Y-H, Wong JT. 2007. Concentration-dependent organization of DNA by the dinoflagellate histone-like protein HCc3. Nucleic Acids Res. 35: 2573-2583.

16. Chan Y, Kwok A, Tsang JS, Wong JT. 2006. Alveolata histone?like proteins have different evolutionary origins. J. Evolutionary Biol. 19: 1717-1721.

17. Chudnovsky Y, Li JF, Rizzo PJ, Hastings J, Fagan TF. 2002. Cloning, expression, and characterization of a histone-like 
protein from the marine dinoflagellate Lingulodinium polyedrum. J. Phycol. 38: 543-550.

18. Wargo MJ, Rizzo PJ. 2000. Characterization of Gymnodinium mikimotoi (Dinophyceae) nuclei and identification of the major histone-like protein, HGm. J. Phycol. 36: 584-589.

19. Kohli GS, John U, Figueroa RI, Rhodes LL, Harwood DT, Groth M, et al. 2015. Polyketide synthesis genes associated with toxin production in two species of Gambierdiscus (Dinophyceae). BMC Genomics 16: 410.

20. Zhang S, Sui Z, Chang L, Kang K, Ma J, Kong F, et al. 2014. Transcriptome de novo assembly sequencing and analysis of the toxic dinoflagellate Alexandrium catenella using the Illumina platform. Gene 537: 285-293.

21. Shoguchi E, Shinzato C, Kawashima T, Gyoja F, Mungpakdee S, Koyanagi R, et al. 2013. Draft assembly of the Symbiodinium minutum nuclear genome reveals dinoflagellate gene structure. Curr. Biol. 23: 1399-1408.

22. Roy S, Morse D. 2012. A full suite of histone and histone modifying genes are transcribed in the dinoflagellate Lingulodinium. PLoS One 7: e34340.

23. Bayer T, Aranda M, Sunagawa S, Yum LK, DeSalvo MK, Lindquist E, et al. 2012. Symbiodinium transcriptomes: genome insights into the dinoflagellate symbionts of reefbuilding corals. PLoS One 7: e35269.

24. Lin S, Zhang H, Zhuang Y, Tran B, Gill J. 2010. Spliced leader-based metatranscriptomic analyses lead to recognition of hidden genomic features in dinoflagellates. Proc. Natl. Acad. Sci. USA 107: 20033-20038.

25. Guillard RR. 1975. Culture of phytoplankton for feeding marine invertebrates, pp. 29-60. In Smith WL, Chanley MH (eds.), Culture of Marine Invertebrate Animals. Plenum Press, New York.

26. Geng H, Sui Z, Zhang S, Du Q, Ren Y, Liu Y, et al. 2015. Identification of microRNAs in the toxigenic dinoflagellate Alexandrium catenella by high-throughput Illumina sequencing and bioinformatic analysis. PLoS One 10: e0138709.

27. Galleron C. 1976. Synchronization of the marine dinoflagellate Amphydinium carteri in dense cultures. J. Phycol. 12: 69-73.

28. Livak KJ, Schmittgen TD. 2001. Analysis of relative gene expression data using real-time quantitative PCR and the 2- $\Delta \Delta \mathrm{CT}$ method. Methods 25: 402-408.

29. Lupke M, Frahm J, Lantow M, Maercker C, Remondini D, Bersani $F$, et al. 2006. Gene expression analysis of ELF-MF exposed human monocytes indicating the involvement of the alternative activation pathway. Biochim. Biophys. Acta 1763: 402-412.

30. Kruger NJ. 1994. The Bradford method for protein quantitation. Methods Mol. Biol. 32: 9-15.

31. Shechter D, Dormann HL, Allis CD, Hake SB. 2007. Extraction, purification and analysis of histones. Nat. Protoc. 2: 1445-1457.

32. Edgar RC. 2004. MUSCLE: multiple sequence alignment with high accuracy and high throughput. Nucleic Acids Res. 32: $1792-1797$.
33. Waterhouse AM, Procter JB, Martin DM, Clamp M, Barton GJ. 2009. Jalview Version 2 - a multiple sequence alignment editor and analysis workbench. Bioinformatics 25: 1189-1191.

34. Gasteiger E, Hoogland C, Gattiker A, Duvaud S, Wilkins MR, Appel RD, et al. 2005. Protein identification and analysis tools on the ExPASy server, pp. 571-607. In Walker JM (ed.) The Proteomics Protocols Handbook. Humana Press, New York.

35. Mitchell A, Chang H-Y, Daugherty L, Fraser M, Hunter S, Lopez R, et al. 2014. The InterPro protein families database: the classification resource after 15 years. Nucleic Acids Res. 43(Database Issue): D213-D221.

36. Finn RD, Coggill P, Eberhardt RY, Eddy SR, Mistry J, Mitchell AL, et al. 2016. The Pfam protein families database: towards a more sustainable future. Nucleic Acids Res. 44: D279-D285

37. Kelley LA, Mezulis S, Yates CM, Wass MN, Sternberg MJ. 2015. The Phyre2 web portal for protein modeling, prediction and analysis. Nat. Protoc. 10: 845-858.

38. Mariadason JM. 2008. HDACs and HDAC inhibitors in colon cancer. Epigenetics 3: 28-37.

39. Orphanides G, LeRoy G, Chang C-H, Luse DS, Reinberg D. 1998. FACT, a factor that facilitates transcript elongation through nucleosomes. Cell 92: 105-116.

40. Gornik SG, Ford KL, Mulhern TD, Bacic A, McFadden GI, Waller RF. 2012. Loss of nucleosomal DNA condensation coincides with appearance of a novel nuclear protein in dinoflagellates. Curr. Biol. 22: 2303-2312.

41. de la Espina SMD, Alverca E, Cuadrado A, Franca S. 2005. Organization of the genome and gene expression in a nuclear environment lacking histones and nucleosomes: the amazing dinoflagellates. Eur. J. Cell Biol. 84: 137-149.

42. Rizzo PJ, Noodén LD. 1972. Chromosomal proteins in the dinoflagellate alga Gyrodinium cohnii. Science 176: 796-797.

43. Tomas RN, Cox ER, Steidinger KA. 1973. Peridinium balticum (Levander) Lemmermann, an unusual dinoflagellate with a mesocaryotic and an eucaryotic nucleus. J. Phycol. 9: 91-98.

44. Azevedo C. 1989. Fine structure of Perkinsus atlanticus n. sp. (Apicomplexa, Perkinsea) parasite of the clam Ruditapes decussatus from Portugal. J. Parasitol. 627-635.

45. Marinov GK, Lynch M. 2016. Diversity and divergence of dinoflagellate histone proteins. G3 (Bethesda) 6: 397-422.

46. Figueroa RI, Bravo I, Fraga S, Garcés E, Llaveria G. 2009. The life history and cell cycle of Kryptoperidinium foliaceum, a dinoflagellate with two eukaryotic nuclei. Protist 160: 285-300.

47. Suganuma T, Workman JL. 2011. Signals and combinatorial functions of histone modifications. Annu. Rev. Biochem. 80: 473-499.

48. Marzluff WF, Wagner EJ, Duronio RJ. 2008. Metabolism and regulation of canonical histone mRNAs: life without a poly (A) tail. Nat. Rev. Genet. 9: 843-854.

49. Ehinger A, Denison SH, May GS. 1990. Sequence, organization and expression of the core histone genes of Aspergillus nidulans. Mol. Gen. Genet. 222: 416-424. 
50. Wu RS, Bonner WM. 1981. Separation of basal histone synthesis from S-phase histone synthesis in dividing cells. Cell 27: 321-330.

51. Smith AP, Jain A, Deal RB, Nagarajan VK, Poling MD, Raghothama KG, et al. 2010. Histone H2A.Z regulates the expression of several classes of phosphate starvation response genes but not as a transcriptional activator. Plant Physiol. 152: $217-225$.

52. Sura W, Kabza M, Karlowski WM, Bieluszewski T, KuśSlowinska M, Pawełoszek $€$, et al. 2017. Dual role of the histone variant H2A.Z in transcriptional regulation of stressresponse genes. Plant Cell 29: 791-807.

53. Li M, Shi X, Guo C, Lin S. 2016. Phosphorus deficiency inhibits cell division but not growth in the dinoflagellate Amphidinium carterae. Front. Microbiol. 7: 826.

54. Williams AS, Marzluff WF. 1995. The sequence of the stem and flanking sequences at the $3^{\prime}$ end of histone mRNA are critical determinants for the binding of the stem-loop binding protein. Nucleic Acids Res. 23: 654-662.

55. Yang L, Duff MO, Graveley BR, Carmichael GG, Chen L-L. 2011. Genomewide characterization of non-polyadenylated RNAs. Genome Biol. 12: 1.

56. Lai EC, Burks C, Posakony JW. 1998. The K box, a conserved 3' UTR sequence motif, negatively regulates accumulation of enhancer of split complex transcripts. Development 125: 4077-4088.

57. Singh RK, Paik J, Gunjan A. 2008. Generation and management of excess histones during the cell cycle. Front. Biosci. (Landmark Ed.) 14: 3145-3158.

58. Nelson DM, Ye X, Hall C, Santos H, Ma T, Kao GD, et al. 2002. Coupling of DNA synthesis and histone synthesis in $\mathrm{S}$ phase independent of cyclin/cdk2 activity. Mol. Cell. Biol. 22: 7459-7472.

59. Morillo-Huesca M, Muñoz-Centeno M, Singh R, Reddy G, Oreal V, Liang D, et al. 2010. Accumulation of transcription- evicted histones induces a CLN3-dependent cell cycle delay in G1. PLoS Genet. 6: e1000964.

60. Singh RK, Gonzalez M, Kabbaj M-HM, Gunjan A. 2012. Novel E3 ubiquitin ligases that regulate histone protein levels in the budding yeast Saccharomyces cerevisiae. PLoS One 7: e36295.

61. Commerford S, Carsten A, Cronkite E. 1982. Histone turnover within nonproliferating cells. Proc. Natl. Acad. Sci. USA 79: 1163-1165.

62. Gunjan A, Verreault A. 2003. A Rad53 kinase-dependent surveillance mechanism that regulates histone protein levels in S. cerevisiae. Cell 115: 537-549.

63. Lubec G, Afjehi-Sadat L. 2007. Limitations and pitfalls in protein identification by mass spectrometry. Chem. Rev. 107: 3568-3584.

64. Sterner DE, Berger SL. 2000. Acetylation of histones and transcription-related factors. Microbiol. Mol. Biol. Rev. 64: 435-459.

65. Vaquero A. 2009. The conserved role of sirtuins in chromatin regulation. Int. J. Dev. Biol. 53: 303-322.

66. Wood A, Shilatifard A. 2004. Posttranslational modifications of histones by methylation. Adv. Protein Chem. 67: 201-222.

67. Guerra-Calderas L, González-Barrios R, Herrera LA, de León DC, Soto-Reyes E. 2015. The role of the histone demethylase KDM4A in cancer. Cancer Genet. 208: 215-224.

68. Musselman CA, Lalonde M-E, Côté J, Kutateladze TG. 2012. Perceiving the epigenetic landscape through histone readers. Nat. Struct. Mol. Biol. 19: 1218-1227.

69. Teif VB, Rippe K. 2009. Predicting nucleosome positions on the DNA: combining intrinsic sequence preferences and remodeler activities. Nucleic Acids Res. 37: 5641-5655.

70. Reinberg D, Sims RJ. 2006. de FACTo nucleosome dynamics. J. Biol. Chem. 281: 23297-23301.

71. Burgess RJ, Zhang Z. 2013. Histone chaperones in nucleosome assembly and human disease. Nat. Struct. Mol. Biol. 20: 14-22. 